Igor MANTSUROV, Yana KHRAPUNOVA, Vladyslav MAKHONIN

\title{
EVALUATION OF UKRAINE'S INTEGRATION PROCESSES IN THE GLOBALIZED ECONOMIC SYSTEM OF THE EU
}

\begin{abstract}
The article, in a sense, summarizes the authors' developments for evaluating the qualitative and quantitative characteristics of Ukraine's integration into the European community. Summing up these long-term studies, the article aims to generalize scientific approaches to determining the essence and forms of manifestation of the internationalization and integration of Ukraine into the globalized Euro-Atlantic economic system.

The need to identify promising vectors for improving the economic development strategy of Ukraine in the light of the prospects for its integration into the

(C) Igor Mantsurov, Yana Khrapunova, Vladyslav Makhonin, 2020.

Mantsurov Igor, Doctor of Economic Sciences, Professor, director of Institute for System Statistical Studies, Kyiv, Ukraine. ORCID: 0000-0003-1753-0422, Email: imantsurov@gmail.com Khrapunova Yana, Candidate of Economic Sciences, Associate Professor at the Department of Statistics of State university «Kyiv National Economic University named after Vadym Hetman», Kyiv, Ukraine. ORCID: 0000-0002-6311-3235, Email: yakhrapunova@gmail.com

Makhonin Vladyslav, PhD student at the Department of Statistics of State university «Kyiv National Economic University named after Vadym Hetman», Kyiv, Ukraine. ORCID: 0000-0001-8627-0754, Email: vladyslavmakhonin@gmail.com
\end{abstract}


globalized economic system of European countries determines the relevance of the study conducted by the authors.

According to the results of the study, the following important conceptual conclusion has been made: Ukraine-EU relations have been characterized by dynamic development since the country gained independence, while a number of signed agreements indicate a significant interest of both parties in cooperation. At the same time, in the process of rapprochement between Ukraine and the EU, the impact of negative factors of European integration has also manifested. The latter, in particular, include: inability to bear the financial burden of contributions to the EU; increased competition from firms of the EU member states in the liberalization process, as well as increased openness of the national economy.

Based on the results of the analysis, a scientific concept is presented depicting the integration paradigm of the present, designed to stimulate the creation and implementation of public policy measures aimed at further combining the national economic system of Ukraine with the globalized economy of the EU member states.

\section{Key words:}

internationalization, economic integration, united and integral world, globalization, national system, economy of Ukraine, globalized economy of the EU member states.

JEL: C53, E27.

\section{Introduction}

At the beginning of the third millennium, the world turned into a global economic system. As a result of this, a globally functioning world production and economic mechanism was formed, the components of which were individual national economies. Globalization as a process is a consequence of the development of production capacity and integration of all spheres of public life, as a result of which the production in the country becomes an integral part of the process that occurs at the international or global levels. 
In the modern world of global transformational shifts, Ukraine's awareness of itself as an integral part of modern Europe and a component of European integration processes can rightfully be considered an urgent issue. The desire of Ukraine to integrate into the European political and economic space has been repeatedly declared as a priority vector for joining the world economy. This has raised the issue of developing comprehensive cooperation with European Union members, which is tied with the country's main development prospects (OECD, 2012).

The course towards European integration, however, requires Ukraine to implement standards of a democratic state and socially oriented economy. Achieving economic and social standards of the European Union is one of the most important tasks for Ukraine, the implementation of which is possible only through open dialogue.

\section{Literature review and problem statement}

The study of the problems of integration and cooperation between Ukraine and the EU has been reflected in the works and monographs of such authors as V. Andriyko, V. Bazilevich (2008), I. Berezhnyuk, O. Bilorus (2003), V. Budkin, I. Burakovsky, V. Vergun, A. Galchinsky , N. Grushinskaya, L. Gubersky, L. Klein, G. Klimk, A. Kredisov, D. Lukyanenko, I. Mantsurov (2013; 2014), V. Novitsky, D. North, Yu. Pakhomov, P. Pashko, O. Plotnikov, S. Pyrozhkov (2016), A. Poruchnik (1994), A. Rumyantsev, V. Stepanenko, J. Stiglitz, L. Shevchenko, S. Huntington, E. Kholstinina, O. Chuvardinsky, M. Yakubyak and others.

Determination of previously unresolved aspects of a common problem. The challenges and contradictions in the development of social and economic processes in the Ukrainian space are so dynamic that a number of issues of both theoretical and methodological nature require rethinking and a new interpretation.

The aim of the article is, firstly, to generalize scientific approaches to determining the nature and manifestation forms of internationalization and integration of Ukrainian economy into the globalized economic system of the EuroAtlantic area, and, secondly, to assess the economic consequences of this integration. 


\section{Research results}

Integration, according to the authors, is a global objective historical process aimed at voluntary and mutually beneficial international unification - in one form or another - of different countries into a particular community.

Taking into account the conceptual definition proposed above, it should be noted that human society is the subject of integration as a unifying process. National states - as actors of inter-state relations - make up the elements of the interstate integration complex. Entering legal relations between themselves, states make it possible to create a common international legal order that exists in the format of international law. Thus, international integration processes require states to adhere to certain voluntary limitations of their sovereignty, although international integration should not lead to the loss by states - as key subjects of international law - of their sovereignty (Scholte, 2000).

In accordance with the intended aim, one of the objectives of this article is to introduce a taxonomy of the components that form a common semantic field, which, in turn, combines such economic categories as «internationalization", «economic integration", "united and integral world» and, in fact, "globalization". First of all, it is a question of constructing such a conceptual line of these categories that would not only clarify their definitions, but also help determine the features that unite said categories and form the essential differences between them. Separately, it should be pointed out that all these paradigmatically related categories are interdisciplinary, since they relate to the conceptual frameworks of various social sciences: economics, philosophy, political science, sociology, etc.

Studying the categories and determining the conceptual structure of the theory of globalization allows, from the point of view of dialectical logic, to conceptualize the creation mechanism of the processes of internationalization, international integration and globalization, as well as to formulate a sequence of these processes. Using the principles of dialectical logic, we can draw the following conclusion: the root cause of all these processes is the division of labour as a process in which different types of treatment of objects of labour are divided among themselves, creating new productions, industries and even fundamentally new types of economic activity (Bazylevych, 2008).

The international division of labour includes all countries to varying degrees. The international division of labour in its further dialectical development unconditionally leads to the internationalization of the productive forces of society, capital and labour, which, in turn, contributes to the further development of the productive labour force, its functional complexity and efficiency. Its main forms are international specialization and international cooperation, the highest 
form of which is international integration, which, unlike economic integration, combines production processes of different nature, enterprises, industries and types of economic activity (Lukashevych, 2005).

International economic integration is a sufficiently high, efficient and promising degree of development of the world economy; a qualitatively new and more complex stage of the internationalization of economic relations. Consequently, economic integration can be presented not only as a process of economic cooperation between countries that leads to a convergence of economic mechanisms, but also as a form of intergovernmental agreements that smooths out national institutional, normative legal and currency differences (and so on), and over time, in a sense, even dispels national borders, thus laying the institutional foundation for the formation of qualitatively new trends in the development of society (Bilorus, 2003).

Thus, in full accordance with the laws of dialectics, the internationalization of productive forces, capital and labour is replaced by globalization, which differs from internationalization in that it provokes a peculiar collapse of state borders, undermines the foundations of national sovereignty and lays the foundation for a certain new - global - community. Despite many common features, globalization and internationalization are still qualitatively different processes. In our opinion, from a certain perspective they can be considered as stages that follow each other (Grazhevska, 2008).

Moreover, the globalization of the economy, according to the authors, is not just a continuation and acceleration of the centuries-old process of internationalization and not just an expansion of the scope of the latter. It is primarily a process of evolution of the world economic space into a qualitatively new state, which is characterized by an increase in the economic openness of countries, trade liberalization, international flows of labour, capital, technology, etc. It should also be noted that each stage of the general internationalization of social production (Figure 1) has its own level of productivity of social labour, economic and social development, and so on. In addition, as the results of long-term research show, this level rises sometimes very rapidly - when moving from one stage to the next.

Studying the problems of economic integration between Ukraine and the countries of the Euro-Atlantic area, it is necessary to dwell in more detail on the characteristics that are specific to this process, the essence of which, in turn, is to unite national economies into a globalized system with high level of interaction of components.

To this end, it is necessary to analyse the history of the creation and development of the European Union. According to the Maastricht Treaty, which was signed on February 7, 1992 and came into force on November 1, 1993, the EU is the economic and political union of 28 independent member states located in Europe. The last significant revision of the EU constitutional principles was approved in the 2009 Lisbon Treaty. 
Figure 1

Interconnection of the international division of labour, internationalization, international integration and globalization processes

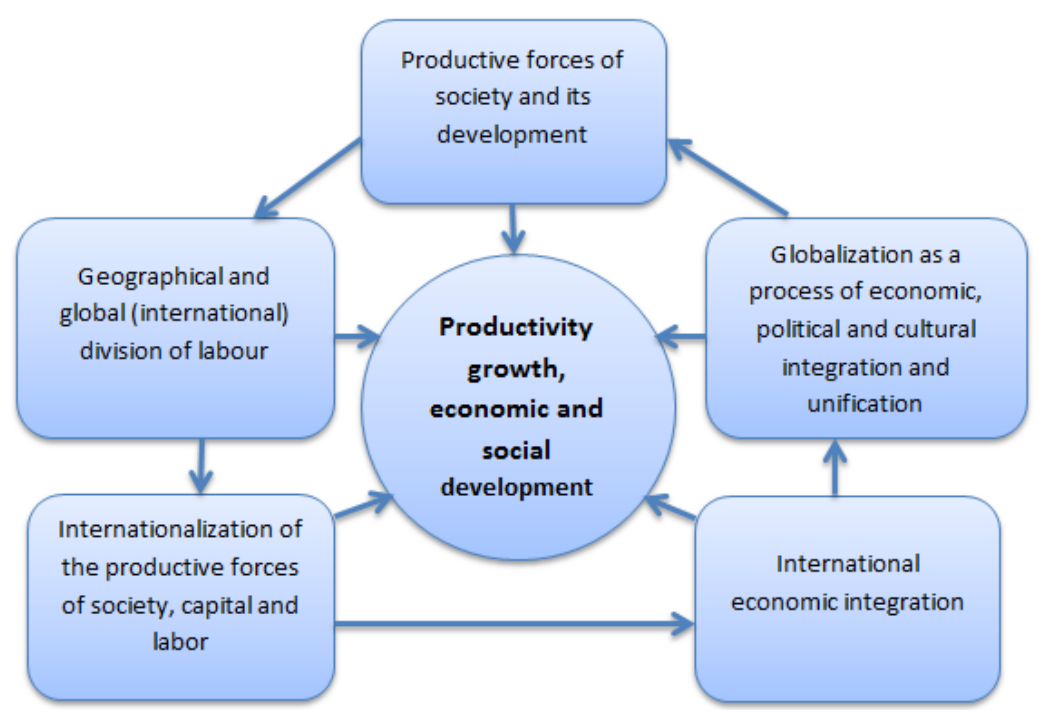

Source: developed by the authors.

The single market operates in the EU through a standardized system of laws that apply in all member states. Passport control has bee cancelled in the Schengen Area (which includes 22 member states and 4 non-EU states). The EU policies are focused on ensuring the free movement of people, goods, services, capital and legislation regarding common issues of justice and support for common trade policies, agriculture, fisheries and regional development.

The intention of Ukraine to build relations with the European Union was first declared in the Decree of the Verkhovna Rada of Ukraine of July 2, 1993, «On the main directions of foreign policy of Ukraine».

Relations between Ukraine and the European Union date back to December 1991, when the Minister of Foreign Affairs of the Netherlands, as a representative of the EU's presiding country, officially recognized independence of Ukraine in a letter on behalf of the European Union. Later, Ukraine confirmed its strategic course towards European integration by adopting, firstly, the Strategy for Integration of Ukraine on June 11, 1998 and, secondly, the Programme for Integration of Ukraine into the EU of September 14, 2000. These documents pro- 
claimed a long-term strategic goal to achieve the European integration of Ukraine.

Pursuant to Article 11 of the Law of Ukraine «On the fundamentals of internal and foreign policies», one of the fundamental pillars of the foreign policy of Ukraine is to ensure the integration of Ukraine into the European political, economic and legal space in order to obtain EU membership.

The negotiation process regarding the adoption of a new agreement between Ukraine and the EU began on March 5, 2007.

The political part of the Association Agreement had been signed on March 21, 2014. The economic part - on June 27, 2014. The Association Agreement between Ukraine and the EU was simultaneously ratified by the Verkhovna Rada of Ukraine and the European Parliament on September 16, 2014.

Its provisional application had started November 1, 2014 and lasted until the Association Agreement between Ukraine and the EU came into force on September 1,2017 . This is an international legal document, which as a legally binding agreement sets out the transition of relations between Ukraine and the European Union from partnership and cooperation to a political association and economic integration.

The association between Ukraine and the EU clearly defines its two main goals - the discussion is about deepening the political association and gradual economic integration.

Achieving the goal of gradual economic integration of Ukraine into the EU is possible through the introduction of conditions for enhanced economic and trade relations, which should lead to the gradual integration of Ukraine into the structure of the EU single market and create an in-depth and comprehensive free-trade area.

Ukraine has given priority to its clear orientation towards the European Union by stipulating it in the Constitution of the country in 2019. It is considered as the basis for the strategy of economic and social development of the state for the next ten years and even a longer term. By signing the agreement with the EU, Ukraine has virtually become part of the European political space.

The most important component of the Association Agreement between Ukraine and the European Union is the creation of a full-fledged free-trade area. According to the clause on the free-trade area between Ukraine and the EU, its components are: maintaining quotas for duty-free exports from Ukraine to the EU on most types of agricultural and industrial products; duty-free imports of most agricultural products from the EU to Ukraine; the removal of subsidies for the export of agricultural products to Ukraine in the EU, etc. 
The Ukrainian side, in addition to partial liberalization of the import regime on agricultural goods, thus, has accepted the right to use protective measures and additional terms of trade, in particular, the application of an input price system. This helps to remove non-tariff barriers to trade and provides Ukrainian exporters with expanded access to the EU market. It became possible to import goods into the EU without restrictions, but at the rate of the current import duty outside the tariff quota.

It is extremely important that the vectors of cooperation defined by the Agreement between Ukraine and the EU serve as the foundation for international organizations' programmes of financing national projects. In particular, one of such projects provides for the creation of a central European gas hub on the basis of Ukrainian underground gas storages. This project harmoniously fits into the current EU policy regarding the creation of a new target model of the EU gas market, which will reduce gas prices for Eastern Europe and the Baltic States by $20-30 \%$. Ukraine should expect approximately the same effect. In addition, the gas hub will resolve the issue of diversification of gas supplies to Ukraine and will attract more investment for the modernization of the gas transportation system, which, of course, should be considered solely as a positive aspect.

It must be emphasized that the Agreement limits the possibility of applying trade restrictions by the EU to Ukraine and improves the prospects for integration at the level of steel producing companies. At the same time, if the issue of modernization is ignored, domestic producers will lose the markets of the EU and other countries to China and Turkey.

At the same time, the competition on the EU market will be intensified by European companies and other large exporters to the EU. This is because the EU steel industry has obvious technological advantages and better access to large steel buyers.

In addition, the EU will make even more efforts to ensure fair conditions of operation, while trade liberalization will enable Ukrainian companies to use their advantages in the form of lower production costs.

Modern international trade relations between Ukraine and the EU are developing in the context of the Association Agreement entering into force. According to its provisions, the parties undertook to remove most of the import duties for bilateral trade during the transition period: for the EU, the latter will last for seven years (until 2023), and for Ukraine-for ten years (until 2026). At the end of the transition period, the EU will remove duties on $95.8 \%$ of product groups for Ukrainian producers. Ukraine, for its part, will remove duties on $96.5 \%$ of product groups.

The process of mutual market opening was asymmetric: duties on $94.7 \%$ of industrial product tariff lines and on $82.2 \%$ of agricultural product tariff lines were immediately cancelled by the European Union. Ukraine, in turn, has so far established a preferential regime for only $49.2 \%$ of its products across the entire commodity nomenclature. The proportions in the tariff protection levels between 
the parties were adjusted accordingly: in Ukraine the average rate of import duty on European products decreased from $4.95 \%$ to $2.42 \%$, while in the EU - from $7.6 \%$ to $0.5 \%$. At the end of the 10 -year transition period, Ukraine will retain the residual levels of import duties for $8.7 \%$ of agricultural output, which will ultimately provide it with a higher level of tariff protection.

Table 1

Characteristics of foreign trade liberalization between Ukraine and the EU in accordance with the provisions of the in-depth and comprehensive free-trade area

\begin{tabular}{|l|c|c|c|c|c|c|}
\hline \multirow{2}{*}{$\begin{array}{c}\text { Product } \\
\text { groups }\end{array}$} & \multicolumn{6}{|c|}{ Average rate of import duty, \% } \\
\cline { 2 - 7 } & $\begin{array}{c}\text { Basic rates (before } \\
\text { the enactment of } \\
\text { the Agreement) }\end{array}$ & $\begin{array}{c}\text { After the enact- } \\
\text { ment of the } \\
\text { Agreement (2016) }\end{array}$ & $\begin{array}{c}\text { After the completion } \\
\text { of the 10-year transi- } \\
\text { tion period (2026) }\end{array}$ \\
\cline { 2 - 7 } & Ukraine & $\begin{array}{c}\text { The } \\
\text { EU }\end{array}$ & Ukraine & $\begin{array}{c}\text { The } \\
\text { EU }\end{array}$ & Ukraine & $\begin{array}{c}\text { The } \\
\text { EU }\end{array}$ \\
\hline $\begin{array}{l}\text { Entire com- } \\
\text { modity no- } \\
\text { menclature }\end{array}$ & 4,95 & 7,6 & 2,42 & 0,5 & 0,32 & 0,05 \\
\hline $\begin{array}{l}\text { Agricultural } \\
\text { products } \\
\text { (HS 01-24 } \\
\text { group) }\end{array}$ & 9,24 & 19,8 & 6,77 & 0,6 & 1,38 & 0,24 \\
\hline $\begin{array}{l}\text { Industrial } \\
\text { products } \\
\text { (HS 25-97 } \\
\text { group) }\end{array}$ & 3,67 & 3,9 & 1,12 & 0,5 & 0,00 & 0,00 \\
\hline
\end{tabular}

Source: developed by the authors using the data of the Ministry for Development of Economy, Trade and Agriculture of Ukraine.

These changes in the regime of tariff regulation of bilateral trade between Ukraine and the EU directly affected the dynamics of the flows of goods and services between them.

In particular, the share of EU countries in the foreign trade turnover of Ukraine increased from $37.5 \%$ in 2015 to $39.7 \%$ in 2016 , and further rose to $41.9 \%$ in 2019 . As a result of this kind of change, the structure and dynamics of the foreign trade turnover of Ukraine in 2019 were as follows (Figure 2 and Table 2). 
Figure 2

The structure of foreign trade turnover of Ukraine, 2019

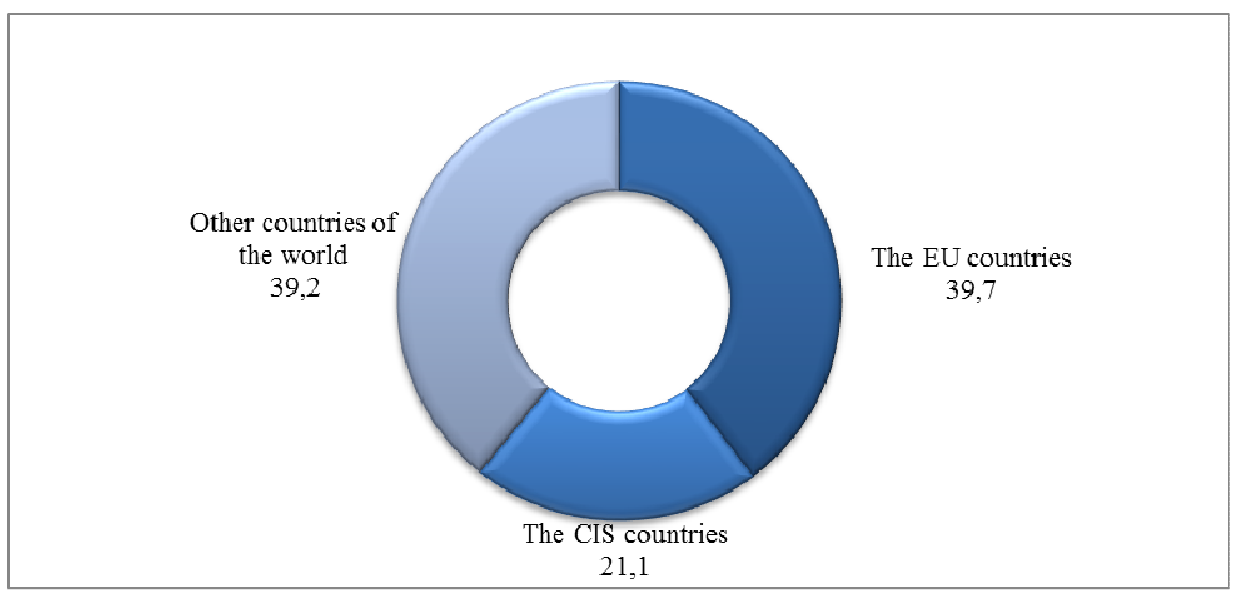

Source: developed by the authors using the data of the Ministry for Development of Economy, Trade and Agriculture of Ukraine.

\section{Table 2}

Export of goods to countries that are the main trading partners of Ukraine, January-October 2019

\begin{tabular}{|c|l|c|c|c|}
\hline No & \multicolumn{1}{|c|}{ Country } & $\begin{array}{c}\text { Export of } \\
\text { goods, mil- } \\
\text { lion USD }\end{array}$ & $\begin{array}{c}\text { Rate of growth / } \\
\text { decline, January- } \\
\text { October 2019, \% }\end{array}$ & $\begin{array}{c}\text { Country's share in to- } \\
\text { tal exports of goods } \\
\text { from Ukraine, \% }\end{array}$ \\
\hline 1 & The EU countries & 17439,8 & 106,1 & 41,9 \\
\hline 2 & China & 2897,6 & 176,1 & 7,0 \\
\hline 3 & $\begin{array}{l}\text { The Russian } \\
\text { Federation }\end{array}$ & 2734,7 & 90,3 & 6,6 \\
\hline 4 & Turkey & 2134,7 & 104,8 & 5,1 \\
\hline 5 & Egypt & 1905,6 & 139,4 & 4,6 \\
\hline 6 & India & 1551,5 & 86,6 & 3,7 \\
\hline 7 & Republic of Belarus & 1284,0 & 120,4 & 2,1 \\
\hline 8 & The USA & 828,6 & 91,4 & 1,6 \\
\hline 9 & Saudi Arabia & 675,4 & 104,5 & 1,5 \\
\hline 10 & $\begin{array}{l}\text { The Republic of } \\
\text { Indonesia }\end{array}$ & 617,5 & 148,6 & \\
\hline
\end{tabular}

Source: developed by the authors using the data of the Ministry for Development of Economy, Trade and Agriculture of Ukraine. 
The gap between the volumes of export and import has a tendency to narrow: the export-import coverage ratio increased from 0.67 in 2013 to 0.88 in 2015 and 0.91 in the third quarter of 2019.

In the export structure of Ukrainian goods to the EU, black metals $(22.9 \%)$, crops $(11.2 \%)$ and electrical equipment $(9.2 \%)$ prevail. In turn, the import of goods to Ukraine from the EU is by and large deeply diversified - with the prevalence of vehicles, equipment and chemical products (Figures 3 and 4).

Under these conditions, as shown by data of the State Fiscal Service of Ukraine, the export of goods from Ukraine to the EU countries in 2019 grew by $15 \%$ and reached $\$ 20.153$ billion. At the same time, the volume of imports last year increased by $10 \%$ and amounted to 24.294 billion dollars. However, even such dynamics in the volume of foreign economic relations between Ukraine and the EU member states did not compensate for the negative foreign trade balance of Ukraine in January-June of 2019 (1619.3 million, which was almost two times more than in the same period in $2018-977.6$ million).

The largest volume of Ukrainian goods had been sold to Poland ( $\$ 2.8$ billion, an increase of $2.1 \%$ ), so exports to this country were ahead of the equivalent to Russian Federation ( $\$ 2.7$ billion, a decrease of $9.7 \%$ ). The top 5 key European exporters also included Italy ( $\$ 2.04$ billion), Germany (\$2.03 billion), the Netherlands ( $\$ 1.5$ billion) and Hungary ( $\$ 1.3$ billion).

\section{Figure 3}

The structure of Ukrainian goods export to the EU in 2019

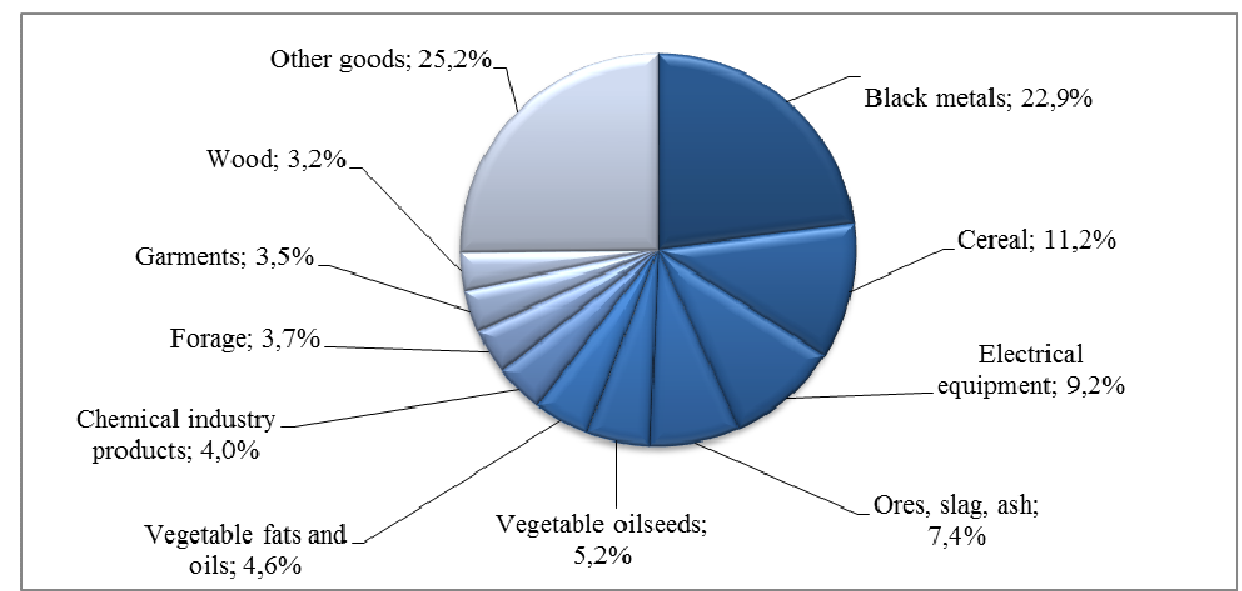

Source: developed by the authors using the data of the Ministry for Development of Economy, Trade and Agriculture of Ukraine. 
Figure 4

The structure of Ukrainian goods import from EU in 2019

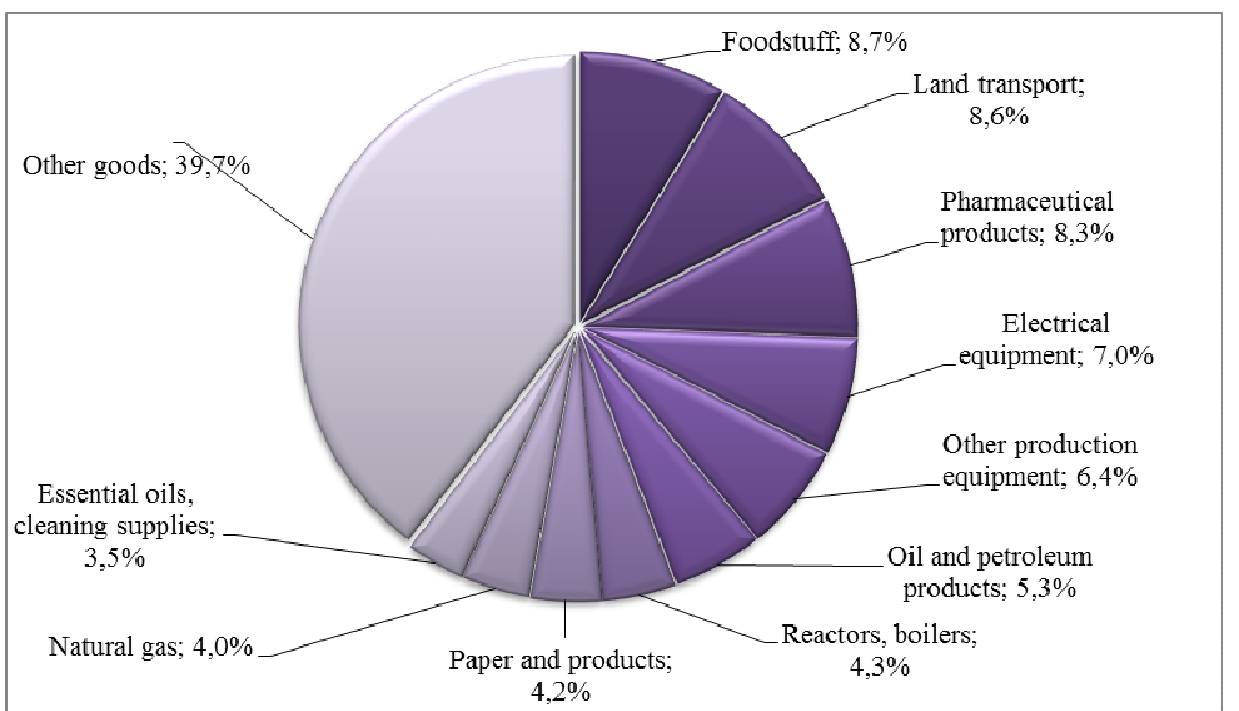

Source: developed by the authors using the data of the Ministry for Development of Economy, Trade and Agriculture of Ukraine.

Aside from the EU, significant volumes were recorded to China (\$2.9 billion) and Turkey (\$2.1 billion).

Along the path to the further development of foreign economic relations between Ukraine and the EU states, however, a number of obstacles are still visible that constrain the potential for economic growth of the parties. Therefore, there is still a series of tariff and non-tariff restrictions on trade between Ukraine and the EU. In particular, the European Union has tariff quotas for 36 groups of agricultural commodities, import duty rates outside of which remain at a barrier level. It is important to note that in the context of the need to overcome the resource-dependent orientation of the Ukrainian economy, the restriction on the export of agricultural raw materials, manifested in the form of tariff quotas, nevertheless obviously hinders the achievement of short-term goals of reorienting domestic producers from the lost sales markets of the Eurasian Economic Union (EAEU), although it cannot be called a full-fledged strategic obstacle to development of trade and economic relations of the country with EU states.

A much more serious problem from the perspective of domestic producers entering the European market is the existence of technical barriers to trade, as 
well as sanitary and phytosanitary measures. Adapting to the quality and safety requirements of products provided by technical barriers and sanitary measures is a complex, lengthy and costly process that blocks access to European markets for most potential Ukrainian suppliers.

For example, the entry into the EU market of domestic producers of poultry meat lasted for five years. As a result, despite the tariff-free quotas provided, the European market for dairy products, lamb, pork and beef remains de facto closed to producers from Ukraine. Over the 5.5 years of the validity of these quotas (starting in April 2014), export to the EU for these product groups has not started.

Along with significant tariff and non-tariff barriers, the entry of domestic producers into the EU markets is also significantly complicated by restrictions related to access to financial resources. Compared to EU countries, interest on export loans, as well as the export insurance cost in Ukraine is much higher, which puts many Ukrainian manufacturers in obviously disadvantageous conditions-again, comparing with European ones. Moreover, in the EU countries there are national state agencies that provide preferential loans for export loans, insurance and export guarantees - Export credit agencies.

The role played by export credit agencies (ECA) in the development of international trade is constantly growing: the dynamic growth of profits and the level of activities of leading ECAs are good examples in this regard.

Given the fact that Ukraine does not have the proper state support mechanisms for export financing and insurance, domestic exporters, in principle, work in conditions of unequal competition in the international markets for goods and services. And taking into account the specifics of the current state of the Ukrainian economy, where, due to limited effective demand on the domestic market, the supply of goods and services for export is almost the only means of developing Ukrainian enterprises, the need to establish appropriate institutional and financial state support for the effective implementation of export potential by launching an effective export credit agency is gaining much more relevance.

The onerousness and excessive complexity of customs procedures in domestic practice remains another important problem in the development of foreign economic relations between Ukraine and the EU. In Ukraine, there is a host of urgent issues regarding the implementation of export customs operations, and the modern practice of launching these operations by authorized state bodies is destructively behind the experience of developed countries (Scholte, 2000).

Thus, the effectiveness of government agencies that regulate export and import procedures directly affects export volumes. The complex state licensing system and the non-transparent structure of state control of export and import operations largely acts as a limiting factor in the development of international trade. Excessive bureaucracy in the field of foreign economic activity leads to a rapid increase in transaction costs in foreign trade. As a result, transaction costs 
in Ukraine reach $40 \%$ of the cost of foreign trade operations, while in the EU countries these costs are only 3-5\%.

\section{Conclusions}

According to the aim set in the article, one of the tasks is to study the categories and determine the conceptual structure of globalization. Following dialectical logic, the authors managed, firstly, to conceptualize the creation mechanism of the processes of internationalization, international integration and globalization, and, secondly, formulate the sequence of these processes.

It is also proved that in full accordance with the laws of dialectics, the internationalization of productive forces, capital and labour is replaced by globalization, which differs from internationalization in that it provokes a peculiar collapse of state borders, undermines the foundations of national sovereignty and lays the foundation for a certain new - global - community.

The characteristic features and levels of such phenomena as international economic integration and full integration are considered: it's proved that the latter provides for the coordination and implementation of a common monetary, fiscal and credit policy, as well as the launch of supranational authorities, etc.

It is emphasized that a prime example of international integration is European integration - the process of political, legal, economic, social and cultural integration of European nations, including those that are only partially located in Europe.

Considering the fundamental conditions of economic relations between Ukraine and the EU, it is proved that in the process of building economic relations with Ukraine, the EU will make even more efforts to ensure fair conditions of operation, which, along with trade liberalization will allow Ukrainian companies to use their advantages in the form of lower production costs.

At the same time, it is emphasized that European producers guided by their economic interests initiate anti-dumping investigations against Ukrainian manufacturers and monitor cases of distortion of competition, as a result of which the entry of Ukraine into the free-trade area becomes an additional risk factor regarding the formation of import dependence - first of all, the development of Ukrainian machine industry.

Further foreign economic relations between Ukraine and the EU will develop in the context of the Association Agreement entering into force. According to its provisions, the parties undertook to remove most of the import duties for bilateral trade during the transition period: for the EU, the latter will last for seven years (until 2023), and for Ukraine-for ten years (until 2026). At the end of the 
transition period, the EU will remove duties on $95.8 \%$ of product groups for Ukrainian producers. Ukraine, for its part, will remove duties on $96.5 \%$ of product groups.

Under these conditions, as shown by data of the State Fiscal Service of Ukraine, the export of goods from Ukraine to the EU countries in 2019 grew by $15 \%$ and reached $\$ 20.153$ billion. At the same time, the volume of imports last year increased by $10 \%$ and amounted to 24.294 billion US dollars.

It is proved that one of the characteristics any state requires to integrate into the international community or into a certain circle of countries is that the development goals of this state and the economic behaviour of its government adhere to international standards and program documents approved by the relevant community.

At the moment, due to the strengthening of the hryvnia exchange rate, the State budget is losing the predicted revenue, which is traditionally tied to the exchange rate. At the end of 2019, the negative balance amounted to a record 70 billion hryvnias. The negative impact of the NBU currency-related policy on the deficit of the State budget couldn't be compensated even by the positive impact the strengthening of the hryvnia had on latter through savings achieved by the external debt being serviced by the Ministry of Finance, which meant that by the end of 2019 it reached about 20 billion hryvnias.

\section{References}

1. Bazylevych, V. D., \& Bazylevych K. S. (2008). Market economy: basic concepts and categories: textbook (2nd ed.) [in Ukrainian]. Znannia.

2. Bilorus, O. G. (2003). Economic system of globalism [in Ukrainian]. KNEU.

3. Bochan, I. O., \& Mykhasiuk I. R. (2007). Global economy [in Ukrainian]. Znannia.

4. Chukhno, A. A. (2003). Post-industrial economy: Theory, Practice and their significance for Ukraine [in Ukrainian]. Logos.

5. Filipenko, A. S., Rohach, O. I., Shnyrkov, O. I., Budkin, V. S., Veklych, O. O., Hodun, S. D., Dudchenko, M. A., Zablotska, R. O., Kyiak, A. T., \& Savchuk, V. I. (2000). Global economy: textbook [in Ukrainian]. Lybid.

6. Grazhevska, N. I. (2008). Economic systems in the era of global changes: monograph [in Ukrainian]. Znannia.

7. Kastels, M. (2011). Information technologies, globalisation and social development. In E. A. Afonin, V. D. Bondarenko \& A. Yu. Martynov (Eds.), Social globalism: textbook [in Ukrainian]. Osvita Ukrainy. 
8. Lukashevych, V. M. (2005). Globalism: textbook (2nd ed.) [in Ukrainian]. Novyi Svit-2000.

9. Mantsurov, I.G. (2014). Institutional planning in the system of state regulation of the economy: monograph [in Ukrainian]. NDEl.

10. Mantsurov, I. G., Yerina, A. M., \& Mazurenko, O. K. (2013). Macroeconomic statistics: textbook for HEls (I. G. Mantsurova, Ed.) (Vol. 1) [in Ukrainian]. KNEU.

11. OECD. (2012). New Approaches to Economic Challenges - A Framework Paper. OECD Paris.

12. Poruchnik, A. M. (1994) Building the economic mechanism of Ukraine's integration into the global economic systems [in Ukrainian].

13. Pyrozhkov, S. I., \& Khamitov, N. V. (2016). Civilization project of Ukraine: From ambitions to real opportunities [in Ukrainian]. Visnyk of National Academy of Sciences of Ukraine, 6, 45-52. http://nbuv.gov.ua/UJRN/vnanu_2016_6_9

14. Scholte, J. A. (2000). Globalization. A critical introduction. Palgrave.

15. Tymoshenko, O.V. (2016). Economic security of the national economy in the conditions of globalisation: monograph [in Ukrainian]. Nash Format.

16. Yeshchenko P. S., \& Palkin Yu. I. (2005). Modern economy: textbook [in Ukrainian]. Vyshcha shkola. 